\title{
Review
}

\section{Political epistemics: The secret police, the opposition and the end of East German socialism}

\author{
Andreas Glaeser \\ University of Chicago Press, Chicago, xxxiii+606pp., ISBN: 978-0226297934 \\ Contemporary Political Theory (2014) 13, e4-e6. doi:10.1057/cpt.2013.6
}

Tocqueville (1998, p. 85) transformed the puzzle of the French Revolution by asking how entrenched habits of thought caused the old regime to 'fall so suddenly and so completely'. Analogously for our day, Andreas Glaeser in Political Epistemics returns us to the East German revolution of 1989 to rethink the sources of conviction and of paralysis among SED party members who had sustained the socialist regime. He breaks ranks with researchers who theorize the German Democratic Republic (GDR) as a macrostructural type, be it a participatory dictatorship or a variant (p. 562). Instead, colligating archival documents with interviews of former Stasi members, Glaeser thickly reconstructs from ground up the prototypical officer's relations to others, to collective belief and above all to his or her own self. He dramatically conveys the unsuspected strangeness of everyday action under the regime while pointing us toward assumptions both novel and universal about individuals' precarious investments in political ideals.

To condense the impressive results into mere theory would oversimplify this massive book. In effect Glaeser takes aim at analyses in which culture functions as a malleable tool in the service of shifting interests. He engages instead the profound question of how anyone comes to see herself or himself as endowed with agency in the first instance. In part his response is that agents learn how to validate knowledge to organize experience through time and to invest in worthwhile purposes. However, the status of such primary understandings is treacherous for their owners. We have to imbibe political beliefs in order to create agentic selves and to anchor repeatable action (p. 42). But this appropriation may ultimately lead us to fetishize belief by turning its performative affirmation into a final end apart from contingency and finitude. That is why many East Germans came not only to use Marxist-Leninist theory - as an ethos it possessed them. Glaeser finds that long after the disappearance of the GDR, some Stasi members remained partial to socialism and enacted the distinctions of taste that originally marked the socialist habitus.

(C) 2014 Macmillan Publishers Ltd. 1470-8914 Contemporary Political Theory Vol. 13, 1, e4-e6 
In the heyday of the GDR, Stasi members 'objectified' themselves through remarkable habits. As young students, some had allegedly lapsed by playing cards or by donning ostentatious clothing. In interviews they still endorsed the heavy punishment they received for this slight slacking. Glaeser suggests that this interminable self-criticism reveals how one's value to oneself depended on behavioral signs. Even a head of the Stasi, Erich Mielke, appears to have been plagued by the anxious thought that if he did not penetrate every source of deviance in the country, the party would be justified in replacing him for failings of character (pp. 471-472). Ordinary Stasi members learned to avoid Western TV broadcasts, as if the outward act of watching could damage their inner worth. To infiltrate dissident circles required interaction with suspects, a potential threat to the purity of the Stasi itself. In consequence, Stasi spy reports on the citizenry had to display narrative distance from deviant opinions in order to counter the otherwise automatic diagnosis of co-contamination.

Behind these details, Glaeser sights the workings of post-war Marxist-Leninist ideals. In the economic and moral wreckage of the immediate post-war years, youth and anti-fascist workers built their lives on the premise that monolithic commitment to socialism was sufficient for overtaking the West. Glaeser reconstructs the reasoning through which Marxism's emphasis on labor's productivity as the key to growth led Party members to philosophical idealism. It enabled them to suppose that inspired intentions were enough for socialist workers to outperform their capitalist counterparts. This cult of success via a shared ethos makes it potentially incidental for social scientists to explain notorious Stasi practices of surveillance by invoking cynical power interests. 'The [Stasi] attempt to discover a proclivity for party-critical thinking and to preempt its appearance in public', Glaeser concludes, 'is fully comprehensible from within the party's understanding about itself and the world' (p. 159). Glaeser is compelling as he tacks between interpreting East German ideology as a cultural constellation, thus protecting its logic and corroboration, versus evaluating that ideology as part of larger world-historical developments.

For the specific puzzle as to why the East German regime dissolved without a shot being fired, political analysts do not have to adjudicate on whether inbuilt economic underperformance structurally dooms all socialist regimes. It is enough to show that the Stasi, as well as broader social strata who were absorbed in socialist ritual, deprived themselves of the modicum of flexibility required to initiate reform and to prolong the regime (p. 528).

The historical import of this book rests therefore on its demonstration that the speechlessness of East German elites in Autumn 1989 is explained by the Party's inherited epistemology (p. 7). Granting that this interpretation grasps events, does it bear adequate depth? For example, a realist might insist that the adequate condition of the regime's viability, especially after 1961, was to block its citizens' escape. In 1988, the Stasi had crisis plans for arresting or interning exactly 3681 individuals (Wunnicke, 2008, p. 133). Once Hungary opened its gates to the West for East 
Germans in Summer 1989, increased repression inside the GDR would have led to a population hemorrhage. Yet by that point, the country had landed in such a self-destructive debt crisis, that it is difficult to envisage how socialists could have believed in the possibility of economic reforms inside the system (Maier, 1997, pp. 61-78). It may be true that practical understandings among the generation in power excluded innovative action, but once the financial crisis became tangible, were there solutions about which party members, blinders removed, could have spoken? In open debate in the weeks following the dismantling of the Berlin wall, the apparent absence of workable plans for a socialist future suggests not (Süß, 1999, pp. 416, 431). This is scarcely to prejudge socialism's feasibility in other settings.

It may be impossible to demonstrate that precisely because elites fetishized doctrine they were incapable of reorienting pragmatically - we know only that similarly to some capitalist politicians, they happened not to do so as their state approached insolvency. Glaeser suggests that even Stasi agents were converting to the necessity of basic reform (pp. 542, 558). A deeper explanation for elite inaction therefore may lie in a constant of the international setting rather than in rigid ideology. In my experience, East German factory workers no later than September 1989 discussed unification under West German auspices. Such expressions of opinion warrant the hypothesis that in the strange condition of a divided nation, any GDR that entertained market-friendly reforms would risk its rationale for not becoming part of the Federal Republic. It is nonetheless a sterling event for this book to probe the foundations of social explanation.

\section{References}

Bruce, G. (2010) The Firm: The Inside Story of the Stasi. Oxford: Oxford University Press.

Maier, C.S. (1997) Dissolution: The Crisis of Communism and the End of East Germany. Princeton, NJ: Princeton University Press.

Süß, W. (1999) Staatssicherheit am Ende. Berlin, Germany: Ch. Links Verlag.

Tocqueville, Alexis de (1998) The Old Regime and the Revolution. Translated by John Bonner Chicago, IL: University of Chicago Press.

Wunnicke, C. (2008) Wandel, Stagnation, Aufbruch: Ost-Berlin im Jahr 1988. Berlin, Germany: Der Berliner Landesbeauftragte für die Unterlagen des Staatsicherheitsdienstes.

Richard Biernacki

University of California, San Diego, La Jolla, USA 